\title{
IGNORED STATE INTERESTS: THE FEDERAL GOVERNMENT AND INTERNATIONAL EFFORTS TO UNIFY RULES OF PRIVATE LAW*
}

\section{Kurt H. Nadelmann $\dagger$}

Under our system of government, how are interests of the states of the Union attended to when the United States Government is asked to participate in international efforts to unify rules of private law and the area of law involved is not amenable to federal legislation? The history of international unification efforts yields instructive information, especially from the fields of private international and commercial law. It shows, as will be seen, that no resort has been had to the treaty-making power of the Federal Government and that, indeed, the solution to the problems involved must be sought elsewhere.

\section{I.}

The question under investigation arose for the United States for the first time, it seems, about eighty years ago. In 1874, the Government of the Netherlands informed the United States that it had proposed to the Governments of Austria, Belgium, France, Germany, Great Britain, and Italy to send delegates to a conference on Enforcement of Foreign Judgments. The United States Government was asked whether it cared to send a delegate to the conference. ${ }^{1}$ An elaborate memorandum ${ }^{2}$ was transmitted on the necessity of improving the conditions under which judgments obtained in the proper jurisdiction may be enforced abroad. The need for uniform rules on the subject had been stressed at international conferences held a few

* This article is an extension of a paper read before the Annual Meeting of the American Branch of the International Law Association, New York City, May 9, 1953.

$\dagger$ J.U.D., Freiburg in Breisgau, 1921; Lic. en Dr., Paris, 1934. Lecturer in Law, New York University School of Law. Member, Board of Editors, American Journal of Comparative Law; Executive Committee, American Branch, International Law Association.

1. U.S. Foreign Rex.: 1874 at 789 (Dep't State 1874) ; BrJLAGEN VAN DE HANDElingen DER TWEede KaMer DER Staten-GeNERAal 1873-1874 $\mathrm{n}^{\circ} 117$, at 31 (Netherlands); Id. $n^{\circ} 113, \mathrm{~A}$, at 10 .

2. U.S. Foreign ReL.: 1874 at 791 (Dep't State 1874). For a summary of the memorandum see Pradier-Fodéré, 1 Journal DU DroIt InTERnational PRIvé 159 (France 1874) (hereinafter CiUneT) and FIORE, DroIt Iñternationat PrIvE xxvii n.1 (Pradier-Fodéré's trans1. 1875). 
years before ${ }^{3}$ and the Dutch jurist T. M. S. Asser had called for an international agreement on the subject. ${ }^{4}$ The Netherlands Government expressed in its memorandum the view that rules adopted by the planned conference would be submitted for the approval of the Governments and would form the basis of a uniform codification of the matter in the various countries, either by obtaining in each of them the sanction of the legislative branch, or by becoming the subject of treaty stipulations. "In both ways," it was said, "the object would be obtained." 5

The Secretary of State, Hamilton Fish, acknowledged the note, adding: ". . . as the subject is of great importance in itself and quite novel to this Department, it will require deliberate consideration." " The answer of the Secretary, given after a lapse of more than two months, was: ". . . the subject has received the careful and deliberate consideration of this Government, which finds itself constrained to say that the difficulties are so great in the way of carrying into effect the project, arising from the nature of the organic Constitution of the United States and the relations of the States to the Federal Government, that it is not thought best to attempt it." 7

The planned conference did not take place. Various governments declined the invitation. ${ }^{8}$ The German Government felt that it had first to achieve the internal unification of the law in the Empire. France took the view that the topic was too delicate to be treated at a general conference and that it should be discussed among individual countries interested in an agreement. ${ }^{9}$ Among the countries which gave favorable replies was Italy. This was no surprise, since Mancini, on behalf of the Italian Government, had visited the governments of Belgium, France, and Germany in 1867 to try to prepare the way for an agreement on uniform rules of private international law. ${ }^{10}$

3. See 1 Annales de L'Assoctation Internationale pour le Progrès des ScIENCES Sociales 226 (1862) (Brussels Congress 1862);2 id. at 152 (1863) (Gand Congress 1863); 3 id. at 198 (1864) (Amsterdam Congress 1864). From Great Britain, Westlake had taken a prominent part in the discussions.

4. Asser, De l'effet ou de l'exécution des jugements rendus à l'étranger en matière civile et commerciale, 1 REVUE DE DROIT INTERNATIONAL ET DE LÉGISLATION CoMparée 82, 408, 473 (France 1869).

5. U.S. Foreign ReI. : 1874 at 793 (Dep't State 1874).

6. Id. at 794. (Note of March 19, 1874).

7. Id. at 795 (Note of June 4, 1874).

8. See BiJlagen, op. cit. supra note 1 : Handelingen DER TweEde KaMer 1874 $1875309,310,315,316$ (Netherlands). Cf. Buzzatr, TRATTATo DI Dirito INTERNazionale Privato Secondo le Convenzioni deli' Aja 22 (1907); Buzzati, Droit International Privt 23 (Rey trans1. 1911).

9. See Renault, Le droit international privé et la Conférence de la Haye, 9 Anates de L'Ecole Libre des Sciences Politiques 320 (France 1894).

10. See Mancini, De lutilité de rendre obligatoires pour tous les Etats, sous la forme d'un ou de plusieurs traités internationaux, un certain nombre de règles 


\section{II.}

Not much more than a year after the inquiry from the Netherlands, the United States Government found itself once more with an invitation to attend an international conference for the unification of the law; this time it came from an American State. The Government of Peru had decided to try to assemble a conference of jurisconsults from all American States for work on the unification or harmonization, as far as possible, of the legislations of the different American States. The letter of invitation of December 11, 1875, ${ }^{11}$ listed the following topics as possible subjects for consideration: (1) as a general basis for all cases not specially indicated, the procuring of uniformity of legislation on private law, so far as the particular circumstances of each country will permit it, and, with regard to points where achievement of uniformity is impossible, embodying in the respective codes the rules according to which conflicts arising from the diversity of the laws shall be resolved; (2) granting in each State to citizens of the others the same civil rights as are enjoyed by its own citizens; (3) making the legislation on marriage between nationals, and between nationals and foreigners, uniform as far as possible; (4) establishing uniformity in the forms of contracts and documents creating obligations; (5) fixing common rules for the enforcement of judgments in civil matters and for the carrying out of letters rogatory; (6) determining in the respective codes the instances of extradition and the modes of effecting it; (7) making commercial legislation, especially in matters of bankruptcy and priorities, uniform; (8) establishing common rules for copyright; (9) making the laws on weights, measures, and coinage uniform; (10) establishing a postal convention among the American States.

The Secretary of State, still Hamilton Fish, declined the invitation in an elaborate answer which is reproduced in full because it seems to have been published only in Peru. ${ }^{12}$ Dated January 24, 1876 , the reply reads : ${ }^{13}$

"In reply, the undersigned is directed by the President to say that while some of the points suggested for consideration are

générales du Droit international privé pour assurer la décision uniforme des conflits entre les différentes législations civiles et criminelles, 1 CLUNET 221, 236 (France 1874). On Mancini see, Serent, The Italian Conception of International Law $\S 64$ et seq. (1943).

11. 2 Congresos Americanos de Lima 119, 120 (Ulloa ed. 1938) [Translated in Field, Outzines of an International Code 671 (2d ed. 1876)].

12. 2 id. at 134 .

13. National Archives, Record Group 59: General Records of the DepartMIENT OF STATE (Communications to Foreign Sovereigns and States, Vol. 4 (18651877)). 
regarded as more or less desirable, others may be neither desirable nor attainable. The common law, so called, of the United States is the same as that of England from which most of the people in this country sprung. That law, especially in its administration, is believed to be widely different from the law of the Continent of Europe and especially of the Iberian Peninsula whence the governing class in the Spanish American States has mostly derived its origin. The law of the Continental Europe generally, is based for the most part, on what is commonly known as the 'Corpus Juris Civilis.' That system of law is undoubtedly highly valuable and is founded upon those principles of morality which are acknowledged everywhere. This is especially true of the law of contracts. The wisdom of the Roman law on this subject has been recognized by the law making powers, and by the judicial tribunals of Great Britain and the United States.

"Another objection to our uniting in a Congress like that referred to, is that, pursuant to the Constitution of the United States, the several States have reserved powers which it is not competent for this government to trench upon either by Act of Congress or by Treaty with a foreign power. Some of the subjects indicated in the note of the Honorable Minister of Foreign Affairs of Peru, as proper for consideration of the proposed Congress, are such as this Government has no authority to entertain, as they are under the exclusive jurisdiction of the several States of the Union. While, therefore, the proposition which the note offers will be held in that respectful consideration which the importance of its subject and the high source from which the invitation comes, warrant and require, the undersigned cannot venture to give encouragement that this Government will, in the end, adopt the suggestion. It is believed that whatever may be materially desirable not already embraced in existing treaties, may be introduced into others in conformity with the organic law of the Republics and with the approval as well as to the general advantage of the inhabitants."

A resolution was afterwards introduced in the United States Senate that the President arrange for having the contemplated congress held in the United States and appoint five delegates. ${ }^{14}$ David Dudley Field lost no time in expressing, in the preface to the second edition of his Outlines of an International Code, ${ }^{15}$ regret that the invitation was not accepted. As early as 1866, at the Manchester meeting of the (English) National Association for the Promotion of Social Science, ${ }^{18}$ he had proposed the draft of a Code of Public and Private

14. 4 Cong. Rec. 1968 (1876). Cf. 13 Albany L.J. 239 (1876).

15. New York, 1876 (First published in 1872).

16. Transactions Manchester 42 (1867). 
International Law, a proposal which led to his drafting the famous Outlines.

The Congress of Jurisconsults took place; it was held at Lima in 1877. Draft conventions were signed on various topics of private international law as well as on extradition, and a draft was prepared of uniform rules for conflicts in commercial matters. ${ }^{17}$ Although the conventions were not ratified, they furnished important material for the South American Congress on Private International Law, which convened at Montevideo in 1888 and which produced the several Montevideo Treaties on Private International Law, ratified by and still in force between a number of South American States. ${ }^{18}$

Perhaps as an aftermath of the Lima Conference, Brazil, which had declined to attend the conference, undertook on its own to negotiate conventions with other states on letters rogatory. It signed such a convention with Uruguay and early in 1879 , it approached the United States, as it did other States, with the proposal to conclude similar agreements. On May 23 of that year, the Secretary of State replied: "The United States does not consider the execution of letters rogatory a matter for treaty regulation." 19

\section{III.}

The third invitation extended to the United States to attend an international conference on unification of private law came from Italy, in 1884 . The episode seems to be little known.

In 1883, the Association for the Reform and Codification of the Law of Nations-today called the International Law Associationhad its annual conference in Milan. Execution of Foreign Judgments was on the program, and a committee had prepared a report on uniform rules. ${ }^{20}$ The conference adopted a resolution which stressed the importance of an international agreement on the topic and set forth some basic principles for such an agreement. It furthermore expressed the desire that a diplomatic conference be called for further consideration of the matter. ${ }^{21}$ The president of the conference was asked to communicate the resolution to the Italian Minister of Foreign Affairs, Mancini, with the request that the Italian Government under-

17 See 2 Congresos Americanos de Lma 343, 383, 406 (Ulloa ed. 1938).

18. 2 International American Conference, Reports of Committees and Discussions THEREON 884 et seq. (1890).

19. See Briggs, Cartas Rogatortas Internacionaes 307 (1913).

20. Association for the Reform and Codffication of the Law of Natrons, Report of the Eleventh Annual Conference, Mithan, 1883118 et seq. (1884).

21. Id. at $129-30$. 
take the necessary steps to obtain consideration of the resolution by the governments of the other civilized nations. ${ }^{22}$

In March of 1884, Mancini instructed the diplomatic representatives of the Italian Government in the capitals of the world to transmit the resolution of the Milan Conference to the respective governments with a tentative suggestion for a diplomatic conference to be held in Rome. $^{23}$ From Washington on April 17, the Italian Minister reported to Mancini that the Secretary of State had promised a definitive answer after consultation with the Attorney General and, possibly with Congress. ${ }^{24}$

The Attorney General, Benjamin $\mathrm{H}$. Brewster, gave his views on the proposals of the Milan Conference to the Secretary of State in an opinion dated December 12, $1884 .^{25}$ Under the Milan proposals, judgments of a court of proper jurisdiction were to be recognized if the parties had been duly cited and if the judgment was not against the public policy in the country of recognition. No examination of the merits of the decision would be undertaken, and forms and means of execution would be governed by the law of the country of execution. Rules on jurisdiction should be agreed upon at the contemplated conference. If a state did not wish to enter into a formal agreement, it was hoped that the rules agreed upon would be introduced into the domestic legislation so as to make the law on foreign judgments uniform. In his Opinion, the Attorney General expressed the view that the proposed rules were in accord with the American doctrines and that adoption of the proposals by the United States Government would effect no material change, nor lead to any improvement in the existing state of American law on the subject.

Six days later, on December 18, the Secretary of State, Frederick T. Frelinghuysen, transmitted the Opinion to the Italian Minister with a letter stating: "It appears that the Government of the United States, in view of these statements, would hardly be justified in adhering to such an international agreement as that proposed." 26

22. Id. at 133 .

23. Atti Parlamentari (Legislatura XV-Prima Sessione 1882-83-84-85) Camera dei Deputati (No II decies (Documenti)), Documenti Diplomatici presentati alla Camera dal Ministro degli Affari Esteri (Mancini) con lettera alla Presidenza in dato 28 giugno 1885; Negoziati e Convocazione di Conferenza Diplomatica in Roma per norme convenzionali di diritto internazionale privato e per la esecuzione dei giudicati stranieri (1881-85) 82 (1885) (hereinafter: Documents Diplokraticr).

24. $I d$. at 102.

25. 18 Ors. ATr'y GEN. 84 (1890).

26. Natyonal Archives, Record Group 59: General Records of the DeParmant of State (Notes to the Italian Legation, Vol. 8). 
Mancini, who had received favorable replies from all other countries except the German Empire, ${ }^{27}$ found the answer from Washington illogical and on January 14, 1885, instructed his Minister to once more apprgach the Secretary of State. He was to point out that, if the American law was in accord with the Milan proposals, the United States had every interest in participating in the proposed conference, because other countries refused to consider foreign judgments conclusive as to the merits and insisted on examination ex integro. Therefore, an international agreement reached at the conference could only improve the position abroad of American judgment creditors. ${ }^{28}$ The Italian Minister passed Mancini's observations to the Secretary of State ${ }^{29}$ and reiterated the request for re-examination after the new administration had taken office, ${ }^{30}$ but nothing came of it.

The contemplated conference did not take place. There had been an outbreak of cholera in Northern Italy, and a Sanitary Conference had been convened in Rome. On June 28, 1885, shortly before he resigned as Minister of Foreign Affairs, Mancini instructed the diplomatic representatives in the foreign capitals to announce a postponement of the conference, since the Italian Government felt that the Sanitary Conference should first terminate its work. ${ }^{31}$ Mancini's successor made no effort to convene the conference.

IV.

In 1888, the Congress of the United States passed an act authorizing the President to call an International American Conference for the purpose of discussing and recommending for adoption to the respective governments some plan for the settlement of disagreements and for considering questions relating to the improvement of business intercourse and means of direct communication between the participating countries. ${ }^{32}$ The Conference, which met in Washington in 1889 , appointed a number of Standing Committees, among them one on International Law. The International Law Committee received the

27. Documenti Diplomatici 146. The favorable reply of Great Britain is at 93, cf. Association for the Reford and Codification of the Law of Nations, REPORT OF THE THIRTEEnTH Conference, London, 1887, 168 (1887) (Statement in the House of Commons).

28. Documenti Diplomattci 157; Contuzzi, La convocazione di una conferenza diplomatica in Roma per norme convenzionali di diritto internazionale privato e per la esecuzione di giudicati stranieri, 10 FILANGIERI 765, 778 (1885); CoNTuzzI, COMMENTAIRE thÉoRique et PRATIQUE DES Conventions dE LA HAYE CONCERNANT LA CODIFICATION DU DROIT INTERNATIONAL PRIVÉ 13 (1904).

29. Doctmenti Diplomatici 159 (Note of Feb. 10, 1885).

30. $I d$. at 160 (Note of March 11,1885 ).

31. Id. at $161 ; 13$ Clunet 53 (1886).

32. International American Conference, Minutes 1 (1890). 
assignment to report uniform rules on private international law in civil and commercial matters and also on the legalization of documents. ${ }^{33}$

In the Committee, it was urged by the representative from Argentina that the Montevideo Treaties on Private International Law of 1889 be recommended for adoption. There was opposition and a compromise report was drawn up asking the governments to study these treaties and to declare within a year whether they would adopt them. ${ }^{34}$ The discussion of the Committee report by the Conference ${ }^{35}$ led to a vivid exchange of views between the chief United States delegate, John B. Henderson, and the delegate from Argentina as to the power of the United States Government to deal with such questions as codification of rules of private international law and uniform rules for authentication of documents. Mr. Henderson said that the questions dealt with in the report fell entirely within the jurisdiction of the states of the Union and that he failed to see how Congress, either through law or by treaty, could undertake to regulate the subjects for the states. He added that of course he could recommend the report to the states. ${ }^{36}$ Intervening, the delegate from Argentina referred to a precedent in his country where procedure is a matter for the Provinces but where procedure had been dealt with in the Montevideo Treaties. He observed that, if the United States could not deal with authentication of documents, execution of judgments, and so forth, the United States would be a ". . . country under a capitis deminutio, with a constitutional capacity to treat inferior to that of all other countries of the world." $37 \mathrm{He}$ added:

"It is claimed that it [the power] is not vested in the Congress of the United States. Would it be then in the States? Evidently not, because the States have no sovereignty recognizable by foreign countries, nor personality before foreign nations, and therefore I said if the States can not make these treaties, and if the Federal power can not, then the United States would be inferior in constitutional capacity with respect to treaties, to all the countries of the world." 38

Mr. Henderson retorted:

"If I am recommended to state these matters for the purpose of arranging between the South American States and the States

33. 1 Internationai American Conference, Reports of Cominittees and DisCUSSTONS THEREON 63 (1890).

34. 2 id. at 876 et seq.

35. Id. at 907 et seq.

36. Id. at $916,917,920$.

37. $I d$. at $921,924$.

38. $I d$. at 925 . 
of this Union a uniformity of law, I am perfectly willing to do so. As a member of the bar association of this country, I can state to this Conference that it has been our purpose for many yearsthat we have endeavored to get uniformity of laws between the States of the American Union on this subject; we are struggling for that now; but when the proposition is made in an International Congress or Conference, that we undertake to do it by the treaty-making power, I must rise and enter my protest. If the treaty-making power is so large as that, then the President of the United States and two-thirds of the Senate may make a treaty abolishing any one of the States of the Union, or they may go to the extent, in defiance of the language of the Constitution, that the American Government shall guarantee to each State a republican form of government-they can by the treaty-making power go to the extent of taking every particle of authority from any one of the States of the Union." 39

The conference unanimously adopted the resolutions of the draft report, namely: (1) that the Governments were recommended to cause the Montevideo Treaties to be studied; (2) that the Governments were ". . . recommended to adopt in the matter of legalization of documents the principle that a document is to be duly legalized when legalized in accordance with the laws of the country wherein it was made or executed; and authenticated by the diplomatic or consular agent, accredited in the nation or locality where the documents is executed, by the government of the nation in which the document is to be used." 40

$$
\text { V. }
$$

The Second International Conference of American States, held in Mexico in 1902, again entered into the field of conflict of laws. A convention was signed for the formation of codes on public and private international law to govern the relations among the American nations. ${ }^{41}$ The delegates from the United States signed "ad referendum." 2 The convention, which provided for appointment of a drafting committee, did not receive the requisite number of ratifications. ${ }^{43}$

The Third International Conference of American States, held in Rio de Janeiro in 1906, was more successful in this respect. A convention was adopted for the establishment of an International Commission of Jurists to draft a Code of Private International Law and

39. $I d$. at $926,928$.

40. Id. at 932; The International Conferences of American States 1889192814 (Scott ed. 1931).

41. The Internationai Conferences of American States 1889-1928 69 (Scott ed. 1931).

42. Id. (preamble).

43. Only Bolivia, Guatemala, and El Salvador had ratified. 
one on Public International Law, regulating the relations between the Nations of America. ${ }^{44}$ This convention was duly ratified, the United States being among the ratifying countries. The International Commission of Jurists was organized, and it held its first meeting in 1912 in Rio de Janeiro. Several committees were created to prepare projects for consideration by the commission at a second meeting scheduled for June, 1914. To the committee for the preparation of the Code of Private International Law only members from Latin American States were appointed. ${ }^{45}$ On Enforcement of Foreign Judgments a draft was immediately drawn up by a subcommittee but was not acted upon. ${ }^{48}$ The outbreak of the First World War delayed, if not interrupted, the work of the various committees, including the one on private international law.

\section{VI.}

In Europe, important developments had taken place. In 1893, the Netherlands achieved what had been tried unsuccessfully before, the calling of a conference on private international law. ${ }^{47}$ A first conference convened that year at the Hague, attended by continental European countries. Three more conferences followed, in 1894, 1900, and 1904. Several conventions on conflict of laws in family law were signed and ratified by a number of countries. ${ }^{48}$ These are based on the principle of nationality. Various of the signatory countries later withdrew from these conventions. ${ }^{49}$ In addition to the conventions on status matters, a convention on international civil procedure (judicial assistance) was signed and ratified by a large group of continental countries.

The question of the United States' adhering to the convention of 1905 on international civil procedure was put before the United States Government by the Netherlands Government in 1922 under the following circumstances. A difficulty had arisen in obtaining execution

44. The International Conferences of American States 1889-1928, 245 (Scott ed. 1931).

45. See H.R. Doc. No. 1343, 62d Cong., 3d Sess. 13 (1913) ; 3 Collected Papers OF JOHN BASSETT MOORE 367 (1944). 1927).

46. 4 A Codificacao AMrericana do Diretto Internacional 412 (Romero ed.

47. See Baldwin, The Beginnings of an Official European Code of Private International Law, 12 YALE Rev. 10 (1903) ; Baldwin, Recent Progress towards Agreement on Rules to Prevent a Conflict of Laws, 17 HARv. L. REv. 400 (1904).

48. See Meilt, Internatronal Crvil and Commercial Law 14, 527 et seq. (Kuhn transl. 1905); Meili, Review of the Foutr Hague Conferences on Private International Law, in OFFICIAL REPORT OF THE UNIVERSAL CONGRESS OF LAWYERS AND JURISTS AT St. Lours 135 (1905). Cf. Baldwin, The Comparative Results, in the Advancement of Private International Law, of the Montevideo Congress of 1888-89 and the Hague Conferences of 1893, 1894, 1900, and 1904, in 2 ProceEdines of the Amertcan Political Science Assoctation 73 (1906).

49. See Gutteridge, The Codification of Private International Law (1951) ; 1 Rabel, The Conflict of Laws: A Comparative Study 31 (1945). 
in the Netherlands of letters rogatory from a Wisconsin court. Compelling a witness to appear before the local court would have been necessary. The Netherlands Government pointed out to the United States Government that, under their statutory law, no witnesses could be compelled under the circumstances to appear, unless the request came from a country signatory of the Hague Convention on international civil procedure. The Department of State, in its reply, noted that the matters covered by the convention are dealt with very largely by the state courts in the United States, and that Congress has not undertaken to pass legislation dealing with those matters; that under the circumstances the Government did not consider that it was in a position to adhere to the provisions of the convention and thereby be in a position to take advantage of the Dutch law carrying the convention into effect. It noted that while letters rogatory from the Netherlands are executed by the courts in the United States, under Dutch law witnesses cannot be compelled to appear before the local courts in response to letters rogatory from the United States. ${ }^{50}$

\section{VII.}

At the Hague, another conference on unification of law took place before the First World War, the International Conference on Bills of Exchange. At this conference, convened in 1910, the United States Government was represented. Charles A. Conant, distinguished New York banker, the United States delegate, had in advance of the conference held a number of general meetings, to which he had invited interested groups, among them representatives of the Commissioners on Uniform State Laws. ${ }^{51}$ At the conference, he pointed out that legislating on negotiable instruments was a matter for the states and that it would be difficult, if not impossible, for the Federal Government to enter into a convention for a uniform law. He informed the conference of the work of the Commissioners on Uniform State Laws and of the enactment of a Uniform Negotiable Instruments Law in most of the states. He said that ". . . the delegate of the United States would assume weighty responsibility, and one difficult to carry into execution in effective form within a reasonable time, if he should join in a recommendation to establish a new code for negotiable instruments as a substitute for existing laws, or if he should recommend important and radical changes in the practice which has grown up under these laws." 52

50. See 2 Hackworth, Digest of International Law 110, 111 (1941).

51. SEN. Doc. No. 768, 61st Cong., 3d Sess. 12 (1911) (international conference on bills of exchange).

52. Id. at 89,319 . For the statement at the sixth plenary session see $i d$. at 117, 321. ACTES DE LA CONFÉRENCE DE LA HAYE POUR L'UNIFICATION DU DRoIT 
The conference adjourned to reconvene in 1912. The Department of State instructed Mr. Conant to keep close contact with the delegates from Great Britain because of the similarity of their negotiable instruments law. Said the instructions:

"It is necessary, however, that even in cooperating with the delegates of Great Britain, you should bear in mind the difference between the system of making laws in the two countries-the system of law governing contracts and bills of exchange being chiefly in the United States the province of the State governments and not of the Federal Government. This fact would limit the ability of the Federal Government to enter into a binding contract or treaty in regard to the law of bills even if no other obstacles existed to such an agreement. You are therefore directed to state to the conference that the Government of the United States, while thoroughly sympathetic with its objects, and willing to welcome cordially an agreement among other States, is not able to accept and adopt a uniform law of bills, but that you can at the utmost report favorably to your Government upon measures to be recommended to the several States." 53

At the conference, Mr. Conant took part in the committee work and obtained a number of changes in the draft of the 1910 Conference, making it conform more nearly than before to the Anglo-American legislation. In declining to sign the drafts adopted by the conference, he promised that the documents would be brought to the attention of the legislatures of the states and the lawyers associations working on the unification of the law. He added that changes in the Uniform Negotiable Instruments Law could not be recommended to the states of the Union unless it were certain that the new Uniform Law would be accepted not only by the civil law countries but within the British Empire as well. ${ }^{54}$

A similar statement was made in 1916 in Buenos Aires on behalf of the United States Government before the Inter-American High Commission on Uniform Legislation when unification of the law of negotiable instruments was considered. ${ }^{\mathbf{5 5}}$

RELATIF À LA LETTRE DE ChANGE 36, 69 (1910). Cf. Burdick, International Bills of Exchange, 6 Ill. L. Rev. 421 (1912) ; LoRENZEN, The Conflict of Laws Relating to Bills and Notes 17 et seq. (1919).

53. Sen. Doc. No. 162, 63d Cong., 1st Sess. 371, 372 (1913) (Bills of Exchange).

54. Id. at $158,159,380.1$ DeUXIÈme ConfÉrence dE IA Haye pour

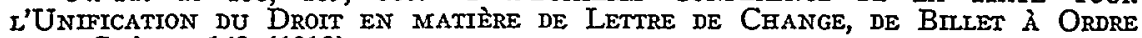
ET DE CHEेQUE 148 (1912).

55. Actas, Infornes, Resoluciones y Documentacion General de la Aita Comision INTERNACIONAL DE LEGISLACION UNIFORME 267, 280 (1916) (Samuel Untermyer, at the 7th session, April 12, 1916); SEN. Doc. No. 739, 64th Cong., 2d Sess. 107 (1917). 


\section{VIII.}

After the First World War, international efforts toward greater uniformity of the law were resumed. In the Western Hemisphere, the Fifth International Conference of American States, held in Santiago, Chile, in 1923, asked the Governments to appoint new delegates to the International Commission of Jurists, established in Rio de Janeiro in 1912.66 For private international law, the commission was asked to first make general policy decisions before engaging in the drafting of a code of private international law. ${ }^{57}$ While no work of consequence was undertaken in Rio, a draft of a code of private international law was produced in 1925 by Dr. Antonio Sanchez de Bustamante y Sirven, of Cuba, as a result of stimulation by the newly formed American Institute of International Law headed by Dr. James Brown Scott. To that Institute, the Council of the Pan American Union had suggested that it prepare a draft or drafts of rules of private international law for submission to the Commission of Jurists in Rio. ${ }^{58}$ In anticipation of such a request, the Institute had appointed a drafting committee of four. Dr. Bustamante, originator of the idea, was on the committee together with three other jurists from Latin America. ${ }^{59}$ Dr. Bustamante produced a draft of a Code of Private International Law, covering all fields of law, civil law, commercial law, penal law (extradition), and international procedure. The draft, approved by the committee and the Institute, was sent to the Pan American Union for the Rio Commission. ${ }^{80}$

The International Commission of Jurists met in Rio de Janeiro in April 1927. James Brown Scott and Jesse S. Reeves were the United States delegates. They both served on the subcommittee formed for Private International Law. Dr. Scott stated at the opening session that this was the first time that the United States was represented at a conference on Private International Law, which field was within the jurisdiction of the states of the Union, but that the Secretary of State, while unwilling to be bound by the proceedings of the commission, was nevertheless desirous of seeing it succeed in its labors. He

56. The International Conferences of Amgrican States 1889-1928 245 (Scott ed. 1931) (Resolution on Codification of American International Law, Point (1)).

57. Id. at 246 n.I Point (9).

58. 7 A Codificacao Americana do Diretro Internactonal 41, 42 (Romero ed. 1927) (Decision of the Council of the Pan American Union of March 2,1925$) ; 7$ Revista de DeREcho INTERNACIONAL 9 (Special Issue 1925).

59. Cf. Bustamante y Sirven, La Comision de Jurisconsultas de Rio DE JANEIRO $Y$ EL DeRECHO INTERNACIONAL 58 (1927).

60. Bustamante y Strven, Proyecto de Codigo de Derecho Internacional Privado (1925); 7 A Codificacao Americana do Diretto Internactonal 215 et seq. (Romero ed. 1927). 
said that the Secretary of State would have the projects, as passed, carefully examined upon their presentation to the Department of State, in order to see to what extent it would be possible for the Government of the United States to accept their conclusions. ${ }^{61}$ The subcommittee made the Bustamante draft the basis for its deliberations and produced a draft for a code of private international law. The commission approved the draft, the United States delegates concurring. In voting for the draft, Dr. Scott declared that he did so in accordance with an earlier statement of his in plenary session which said: ${ }^{62}$

"In so recording its affirmative vote the delegation does not desire to imply that the articles for which it votes are in accordance with the laws of the various jurisdictions of the United States, forty-nine in all. As a matter of fact and as is well known the jurisprudence of the United States is based in general upon the theory of domicile, while the project of the proposed code is based largely upon the theory of nationality. The reason for this affirmative vote is that the delegation of the United States desires to further the work of codification of Private International Law. It desires, furthermore, to make this recognition of what it believes to be a constructive effort of very considerable value, and it desires that, by the adoption of these articles the forthcoming Pan American Conference at Habana may have before it, for its mature consideration, a substantial basis for the discussion of Private International Law.

"In conclusion, the delegation of the United States desires to express the hope that ultimately a code of Private International Law may be proposed for the Americans, by which the opposing principles of the two theories of domicile and nationality may be reconciled. In this happy event it is to be hoped that the United States may be able to join with her sister Republics."

The draft of the International Commission of Jurists of a Code of Private International Law came before the Sixth International Conference of American States, held at Habana in 1928. It was sent to the Third Commission on which James Brown Scott and Morgan J. O'Brien represented the United States. Dr. Scott was made vice-president. In accepting he referred to the special situation in which the United States found itself in the matter. ${ }^{63}$ Later, Mr. O'Brien made the statement that the intention of the American dele-

61. 3 Comision Internactonal de Jurisconsultos Americanos, Reunion de 1927, 8 (Rio de Janeiro 1927); Scott, The Gradual and Progressive Codification of International Laze, 21 AM. J. INT'L L. 417, 448 (1927).

62. 1 International Commission of American Jurists, 1927, MeEting 183 (1928); Scott, op. cit. supra note 61, at 448-9.

63. Diario de Sestones de la VI Conferencia Internacional Americana 155 (1928) (First session, Jan. 19, 1928) (hereinafter Drario); Bustamante Y Sirven, El Codigo de Derecho Internactonal Privado Y la Sexta Conferencia PANAMTERTCANA 72 (1929). 
gation was not to oppose the projected code but that the delegation would be unable to vote for it, as it dealt with internal questions belonging to the jurisdiction of the forty-eight states which had their own distinct organic constitutions. ${ }^{64}$ Dr. Bustamante countered with the remark that the code included both matters coming under the federal jurisdiction and matters belonging to the jurisdiction of the states; that those of the latter type were not numerous and that an investigation of the treaties entered into by the United States showed a number of these subjects dealt with in such treaties signed by the Executive and ratified by the Senate. This was one of the reasons, he added, why the draft provided that the signatory countries were free to adopt parts of the code. ${ }^{65} \mathrm{Mr}$. O'Brien agreed that it was necessary to examine which provisions of the code belonged to the jurisdiction of the Federal Government and which did not. ${ }^{68}$

The American Delegation abstained from voting on the draft which was adopted by the conference and which was given the official name: Bustamante Code. ${ }^{67}$ The Delegation explained its position in these terms: ${ }^{\text {Bs }}$

"The Delegation of the United States of America regrets very much that it is unable at the present time to approve the Code of Dr. Bustamante, as in view of the Constitution of the United States of America, the relations among the States members of the Union and the powers and functions of the Federal Government, it finds it very difficult to do so. The Government of the United States of America firmly maintains its intention not to dissociate itself from Latin America, and therefore, in accordance with Article Sixth of the Convention which permits any Government to adhere later thereto, it will make use of the privilege extended by this article in order that, after carefully studying the Code in all its provisions, it may be enabled to adhere to at least a large portion thereof. For these reasons, the Delegation of the United States of America reserves its vote in the hope, as has been stated, of adhering partly or to a considerable number of the Code's provisions."

The position taken by the United States delegates at Habana in 1928 became in the following year the subject of an important debate at the Annual Meeting of the American Society of International Law. ${ }^{69}$

64. Diario 183, 202 (Third séssion, Jan. 25, 1928) ; Bustamante y Sirven op. cit. supra note 63 , at 83 .

65. See note 64 supra.

66. See note 64 supra.

67. The International Conferences of American States 1889-1928 325 et seq., 443 (Scott ed. 1931).

68. Id. at 371; Lorenzen, The Pan-American Code of Private International Laze, 4 Tulane L. Rev. 499, 519, 520 (1930).

69. 23 Am. Soc'y INT'z L. Proc. 33 et seq. (1929). 
Mr. Jesse S. Reeves was in the chair and Dr. Scott contributed an explanation of the statement of the delegation which he had himself drafted. ${ }^{70} \mathrm{Mr}$. Arthur $\mathrm{K}$. Kuhn advanced the view that, even assuming, as a political decision, that the treaty-making power would not be used for the acceptance of principles of strictly private law applicable within the separate states, the Federal Government could act as agent for the various jurisdictions of the United States in collaborating with other nations upon a basis which might be acceptable to the separate states. "Let us assume," he said, "that legislation were necessary in order to make any such elaborated treaty effective in the separate states; should we be forever dissuaded from taking any forward step because such legislation is necessary?" And he referred to the domestic work of the Commissioners on Uniform State Laws. ${ }^{71} \mathrm{Mr}$. Kuhn was asked whether he had in mind the Wigmore Report suggesting that permission by Congress be given to the individual states whereby they might individually adhere to international conventions. He replied that he had not in mind a delegation of power to separate states to enter into treaties or compacts with foreign governments. His thought was more along the parallel of some of the treaties entered into under the auspices of the League of Nations, as for example those in labor matters, where the nations do not enter upon a treaty setting down a fixed principle, to the observance of which they will hold themselves bound; but where in good faith they say that they will endeavor to obtain suitable labor legislation, sometimes specifying a minimum, but sometimes specifying the exact principle, as near as practicable, within the member states. He thought that it would be quite practical for the Federal Government to enter into a compact of that kind laying down principles of private international law with the understanding that the Government would make an effort in good faith to obtain suitable legislation in the individual states, and thus carry out the principles of the convention. ${ }^{72}$ Another speaker, Professor Quincy Wright, suggested a somewhat different method. $\mathrm{He}$ recalled that there have been some treaties made by the United States which have expressly stated that they shall take effect within a state only after the President has declared to that effect; that formerly it used to be quite common for the British Crown to make a treaty with the statement in the treaty that it would take effect in Canada or in Australia only after it had been approved by the legislative body of that

70. 23 id. at 42 .

71. 23 id. at $33,35,36$.

72. $23 \mathrm{id}$. at 38 . 
Dominion. He saw no reason why the United States could not make a treaty on private international law and put in the treaty itself a statement that the treaty should not apply within the territory of any state of the United States until the President had so declared. This would leave the President free to withhold such declaration until the legislature of a particular state had brought its legislation into conformity with the convention. ${ }^{73}$

The Wigmore Report referred to in the discussion is one that Professor Wigmore submitted in 1921 to the National Conference of Commissioners on Uniform State Laws on behalf of its committee on Inter-State Compacts. ${ }^{74}$ In the part dealing with international relations, with regard to subjects requiring uniformity of commercial legislation with foreign states and not amenable to federal legislation, the report referred to the "helpless and humiliating" position in which the United States was left by the constitutional limitations. ${ }^{75}$ It asserted that the United States would enter into the activity of world legislation as a "self-inflicted cripple," unless certain positive measures were first taken to remove this disability. ${ }^{76}$ The use of the constitutional expedient of state compacts was recommended. First, Congress was to assent to the states making compacts with a foreign nation with reference to the law of a specific subject. States interested would then send delegates to an international conference. Any convention there signed, would then be submitted to the legislature of the state for ratification and upon adoption would become the law of such state. Adoption of such convention by some states would in all likelihood lead to the adoption of similar legislation by other states, and in this fashion uniformity would be gradually attained while the American delegates with their arguments and votes would be enabled to secure the necessary and desirable compromises in favor of American ideas. ${ }^{77}$

There is a comment on this part of the Wigmore Report in a later report of the same committee drafted by James M. Landis and submitted to the conference in $1932 .{ }^{78}$

73. 23 id. at 39,40 .

74. 1921 Handbook of the National Conference of Commissioners on Unifor3r State Laws 299 ef seq. (1921).

75. Id. at 323 .

76. Id. at 321 .

77. Id. at 326 et seq., 355. Cf. Wigmore, A Comment on Mr. Lee's Suggestions [respecting Uniformity of Law, the Treaty Power, and State Compacts], 23 Ins. L. REv. 734 (1929). For earlier statements, see Wigmore, The International Assimilation of Law-Its Needs and its Possibilities from an American Standpoint, 10 InL. L. REv. 385, 396 (1916); Wigmore, Problems of World-Legislation and America's Share Therein, 4 VA. L. REv. 423, 436 (1917), also in WigMore, ProbleMs of LAw 105, 126 (1920).

78. 1932 Handbook of the National Conference of Commisstoners on UNIFORM State Laws 280, 292 et seq. (1932). 
"The conception entertained by your committee in 1921, of the part that interstate compacts might be made to play in the field of world legislation is a significant one, but one which has as yet failed to achieve more than academic distinction. The Anglo-Saxon countries with their age-old pride in the preeminence of their gnarled and twisted common law have not responded to the movements for world uniformity with more than a passing enthusiasm. It is from the continent and such countries, as those of Latin America, bred to continental law that the impetus for world conformity comes. At the moment we are intent both upon unifying our law through legislation and upon ordering and clarifying it by a process of restatement. It may well be that with these two tasks behind us, we will tend to reach out more readily towards aiding in bringing about world clarification. But, so far as the imagination of this committee carries it, no immediate demand for the use of interstate compacts in this field is likely to exist, and when such demand arises there may well be other and more effective legal weapons in our federal arsenal." 79

IX.

The Seventh International Conference of American States, the next following the one in which the Bustamante Code was adopted, dealt anew with unification of private law. The conference, held in Montevideo in 1933, decided that the Pan American Union should appoint a committee of five experts to draft projects for the simplification and uniformity of powers of attorney, and the juridical personality of foreign companies, if such uniformity was possible. ${ }^{80}$ The Committee of Experts appointed by the Pan American Union produced a "Declaration on the Juridical Personality of Foreign Companies" 81 and a "Protocol on Uniformity of Powers of Attorney Which are to be Utilized Abroad." 82 A jurist from the United States had served on the committee.

The first named instrument constitutes a declaration on the part of the signatory countries that the principle enunciated by the Committee of Experts is in harmony with the doctrine established in the laws of the respective countries. The "principle" reads: "Companies constituted in accordance with the laws of one of the Contracting States, and which have their seats in its territory, shall be able to exercise in the territories of the other Contracting States, notwithstanding that they do not have a permanent establishment, branch

79. $I d$. at 293.

80. The International Conferences of American States, First SuppleMENT 1923-1940, 74 (1940) (Resolution 48).

81. For text see 7 Hudson, International Legislation 355 (1941).

82. For text see 8 id. 449 (1949). 
or agency in such territories, any commercial activity which is not contrary to the laws of such States and to enter all appearances in the courts as plaintiffs or defendants, provided they comply with the laws of the country in question." A number of States have signed the "Declaration," the essence of which may be found also in treaties of commerce, the Bustamante Code, and so forth. The United States has signed the "Declaration" with two "understandings." 83

The "Protocol" on powers of attorney is of substantially greater consequence than the "Declaration" which merely tends to restate the law. The Protocol lays down rules to which powers of attorney to be utilized abroad must conform. Powers of attorney executed in one country in conformity with the Protocol and legalized in accordance with the special rules governing legalization shall be given full faith and credit in the other countries. ${ }^{84}$ Under the Protocol, the party challenging the power of attorney has the burden of proof. ${ }^{85}$ This is to be read together with the rules which provide that the attesting official shall certify to the identity and legal capacity of the person executing the instrument; that he shall certify to the authority of a representative executing a power of attorney in the name of a third person and that such representation is legal according to documents exhibited; and that, in addition, in the case of a power of attorney executed in the name of a juridical person, he certify to the due organization, home office, and legal existence of the juridical person and that the purposes for which the instrument is granted are within the scope of its objects and activities. The Protocol was ratified by the United States in $1942,{ }^{86}$ following ratifications by Brazil, El Salvador, and Venezuela. Senate consent was unanimous. ${ }^{87}$

X.

In Europe, after the First World War the activities in matters of unification of private law centered around the League of Nations

83. U.S. Treaty Ser, No. 973 (Dep't State 1941) :

"(1) It is understood that the companies described in the Declaration shall be permitted to sue or defend suits of any kind, without the requirement of registration or domestication.

(2) It is further understood that the Government of the United States of America may terminate the obligations arising under the Declaration at any time after twelve months' notice giverl in advance."

The Declaration has been ratified so far only by the United States and Venezuela.

84. 8 Hudos, op. cit. supra note 81 , at $452-53$ (art. 5 of the Protocol).

85. Id. at 450-51 (art. 1 and 2 of the Protocol).

86. U.S. Treaty Ser., No. 982 (Dep't State 1942).

87. 88 Cong. Rec. 2863, 2865 (1942). On the difficulties in international practice, see Eder, Pozcers of Attorney in International Practice, $98 \mathrm{U}$. OF PA. L. REv. 840 (1950). 
and the Hague Conference on Private International Law. The Hague Conference held two sessions, in 1925 and 1928, with Great Britain taking part for the first time. Topics considered were bankruptcy and enforcement of foreign judgments, succession, and sale of goods. ${ }^{88}$

Of matters handled by the League of Nations a few need mention. The League dealt with "Validity of Arbitration Clauses," which led to the signature of a Protocol; 89 it also dealt with "Enforcement of Foreign Arbitral Awards." One of the members of the Committee of Experts appointed by the Economic Council of the League, which prepared the draft for the convention on Execution of Foreign Arbitral Awards, was an American, Mr. Benjamin H. Conner. ${ }^{90}$ Treaties of Friendship and Commerce concluded by the United States in recent years contain provisions for the enforceability of arbitration clauses in private contracts. ${ }^{91}$

In 1927, the United States received from the League's Committee of Experts for the Progressive Codification of International Law a questionnaire which included questions about a draft convention on judicial assistance in penal matters. The United States Government replied: ${ }^{82}$

“. . . the taking of testimony relating to criminal cases in foreign countries by the use of letters rogatory, with which Article I of the amended draft deals, is a process for which no provision has been made by the legislation of the Federal Government and one which under the system prevailing in the United States can be employed, if at all, only pursuant to the laws of the several states. It is not deemed advisable to make commitments by international convention to change the existing practice in this regard prevailing in the United States. Moreover, evidence obtained in foreign countries through letters rogatory could not be used in criminal cases in the United States, since under the Constitution the accused must be confronted by the witnesses against him.

". . .

"While conventions on the subject of judicial cooperation doubtless serve a useful purpose among countries in close geo-

88. See Gutteridge, The Codification of Private International Law (1951).

89. 2 Hudson, International Legislation 1062 (1931) (Protocol on Arbitration Clauses, Sept. 24, 1923).

90. Draft of Protocol on Enforcentent of Foretgn Arbitral Awards, With REPORT (League of Nations Publications II: Econ. and Financial No. 44) (1927). Cf. Convention on the Exectition of Foreign Arbitral Awards, Sept. 26, 1927, 3 HUDSON, INTERNATIONAL LEGISLATION 2153 (1931). Nussbaum, Treaties on Commercial Arbitration-A Test of International Private-Law Legislation, 56 HARv. L. REV. 219 (1942).

91. See Domke, On the Enforcement Abroad of Anerican Arbitration Awards, 17 LAW \& Contemp. ProB. 545, 549 (1952).

92. 1 U.S. FOREIGN REL.: 1927 at 411, 412 (Dep't State 1942). 
graphic proximity to each other, it is not apparent that uniform application of such agreements is necessary."

The following year, the Governments received for comment the draft, prepared by a committee of experts, of a Uniform Negotiable Instruments Law. ${ }^{93}$ The United States Government replied as follows : ${ }^{94}$

"After consultation, with the appropriate agencies of this Government, the Secretary of State desires to observe, in reply, that the Government of the United States has always held to the attitude that the essential uniformity and other desirable features of the so-called Anglo-American system of bills of exchange should not be sacrificed. However, it feels that, while complete uniformity cannot be obtained, much benefit might arise from the unification of laws pertaining to this subject into two systems rather than the many which now exist.

"The attitude of the United States was expressed by Mr. Charles A. Conant, the delegate of the United States at the Conference relating to the unification of bills of exchange and promissory notes, convened at the Hague by the Netherlands Government in 1910, as follows: 'There is great reluctance in America to undo the long and arduous work which has brought about uniformity in the great majority of states and territories of the Union,' adding that 'an obstacle to uniformity in the United States lay in the fact that the Federal Government had no authority to legislate in the matter.' However, he considered that partial reforms, in accordance with the spirit of the Regulation, were possible, and he assured the Conference of the sympathy of his Government. Mr. Conant made a similar declaration in 1912."

The United States was represented by an observer at the ensuing international conferences for the Unification of Laws on Bills of Exchange and on Checks which produced the two Geneva Uniform Laws and the two conflicts conventions. ${ }^{95}$

XI.

Interrupted by the Second World War, international activities in matters of unification of the law were resumed in recent years. In this hemisphere, the reorganization of the inter-American system,

93. International Conference for the Unification of the Law of Bills of Exchange, Promissory Notes and Cheques, Preparatory Documents (League of Nations Publications II: Econ. \& Financial No. 28) 4, 5 (1929).

94. Id. at 100 .

95. See Hudson and Feller, The Intemational Unification of Laws Concerning Bills of Exchange, 44 Harv. L. Rev. 333 (1931) ; Feller, The International Unification of Lazes Concerning Checks, 45 HaRv. L. REv. 668 (1932). 
which led to the formation of the Organization of American States, had some consequences in this respect. An "Inter-American Council of Jurists" became one of the organs of the Organization of American States. Its statutory assignment is "to serve as an advisory body on juridical matters; to promote the development and codification of public and private international law; and to study the possibility of attaining uniformity in the legislation of the various American countries, insofar as that may appear desirable." ${ }^{96}$ The Inter-American Juridical Committee of Rio de Janeiro was retained as a permanent committee of the Inter-American Council of Jurists. ${ }^{97}$

At its first meeting, held in Rio de Janeiro in 1950, the InterAmerican Council of Jurists entrusted the permanent committee with the study of several topics of public and private international law and of 'unification of the law. The private international law topic is: study of the possibility of revision, in so far as advisable, of the Bustamante Code in the light of the Monterideo Treaties and of the Restatement of the Law of Conflict of Laws, "in order to make these three codifications uniform." ${ }^{88}$ The uniformity of legislation topics include: uniform rules on the sale of personal property, international commercial arbitration, and international cooperation in judicial procedures (judicial assistance). ${ }^{99}$ The United States is represented both on the council and on the permanent committee. The members of the permanent committee represent all member States of the organization. ${ }^{100}$

The permanent committee has produced two opinions on the possibility of revision of the Bustamante Code. The first opinion, ${ }^{101}$ signed by the Latin American members of the committee, deals primarily with questions of system and procedure. The second opinion ${ }^{102}$ is on substance. The United States member has disagreed with some of the recommendations in the opinion; his reasons are given in an elaborate dissenting opinion attached to the report which he has not

96. Charter of the Organization art. 67, in 1948 Inter-American Juridical YEARBOOK 296, 305 (1949).

97. Id. art. 68.

98. 1950-1951 INTER-AMERICAN JuRIDICAL YEARBOOK 289, 302 (1953). See id. at 77, 91 (discussion). Cf. Report of the Inter-American Juridical Committee, in 1949 INTER-AMERICAN JURIDICAL YEARBOOK 320, 324 (1950).

99. 1950-1951 INTER-AMERICAN JuRIDicAL YeARBOOK 289, 302 (1953).

100. Charter of the Organization art. 69, in 1948 Inter-American Juridical YEARBOOK 305 (1949).

101. 1950-1951 InTER-AniericAN JuRIDICAL Yearbook 360 et seq. See Kuhn, Opinion of the Inter-American Juridical Committee on Revision of the Bustamante Code, 46 Ax. J. INT'L L. 317 (1952).

102. Inter-American Juridical Connittee: Second Opinion on the Possibility of Revision of the Bustamante Code, PAN AMERICAN UNION (March, 1953) (mimeo.). 
signed. ${ }^{103}$ On international sale of personal property the permanent committee has produced a draft convention ${ }^{104}$ which the American member did not sign. For uniformity of legislation in international cooperation in judicial procedures it has prepared an elaborate report signed by several members, including the American member. ${ }^{105}$

All these drafts were before the second meeting of the InterAmerican Council of Jurists, held in May and June, 1953, in Buenos Aires. As to revision of the Bustamante Code, the council found that it would be advisable to continue the study with the object of determining with greater assurance the possibility of revising the Code. The permanent committee has been asked to prepare a comparative study of the provisions of the Bustamante Code, of the Montevideo Treaties, and of the rules set forth in the Restatement. The study should include an appraisal of the systematic and technical differences that exist among the three documents, and of the reservations that have been formulated with respect to the Bustamante Code. The permanent committee has been asked to consult the national codification commissions and groups dedicated to the study of private international law, as well as the foremost writers on the subject; and to submit this study to the Governments, so that they may have the opportunity of making comments and observations with respect to the reservations formulated to the Bustamante Code. ${ }^{108}$ On International Sales of Personal Property, the council has found that the permanent committee had not undertaken the indispensable preliminary study of comparative law which would bring out the points of agreement or disagreement in the systems of positive law; and that it had not heard the opinions of scientific institutions, universities, chambers of commerce, jurists, and bar associations, which could make valuable contributions in the determination of the practical problems that might be solved by means of a uniform law. It decided to have the draft uniform law, given the designation "Provisional Draft of Buenos Aires," submitted to the national codification commissions, universities, bar associations, and so forth, for their examination, previous to a further systematic study by the permanent committee. ${ }^{107}$ As for

103. Id. at 28 et seq. (Mr. George H. Owen).

104. Inter-American Juridical Committee: Draft Uniform Law on the International Sale of Personal Property, PAN AMertcan UnIon (March, 1953) (mimeo.) (Statement of the U.S. member at 33).

105. Mr. George H. Owen, Inter-American Juridical Committee: Report on Uniformity of Legislation in International Cooperation in Judicial Procedures ( $J_{u-}$ dicial Assistance), PAN AMIERICAN Union (Nov., 1952) (mimeo.). See Jones, International Judicial Assistance-Report of the Inter-American Juridical Committee, 2 AMr. J. CoMr. L. 365 (1953).

106. Resolution 12, Final Act of the Second Meeting of the Inter-American Council of Jurists 30, PAN ANIERICAN. UNION (August, 1953) (mimeo.).

107. Resolution 13, id. at 31 . 
the Report on Uniform Legislation on International Cooperation in Judicial Procedures, the council has recommended to the Organization of American States that this report be forwarded to agencies devoted to the study and development of civil procedure and of private international law, and to specialists on these subjects, for comments and observations. It also recommended that the comments be printed, and that the permanent committee organize the material received, and write, if desirable, a new report for consideration by the Tenth InterAmerican Conference or by the next meeting of the Inter-American Council of Jurists. ${ }^{108}$ Distribution of the report as recommended has been ordered.

XII.

On the international level, the United Nations has become a potential center for unification work. The Charter of the United Nations stipulates in Article 13(1) (a) that the General Assembly shall initiate studies and make recommendations for the purpose of encouraging the progressive development of international law and its codification. The Committee on the Progressive Development of International Law and its Codification, established by the General Assembly in 1946, considered the establishing of separate international law commissions for public, private, and penal international law, but decided unanimously to recommend to the General Assembly the establishment of a single commission. In the discussions, attention was given to the work done for private international law by the Hague Conferences on Private International Law, and the report submitted by the committee to the General Assembly contains this footnote: ${ }^{109}$

"It appeared to be the feeling of the Committee that the International Law Commission should not do anything which might detract from the valuable work being done in the field of the development and codification of private international law by the Hague Conference on Private International Law. It is therefore recommended that the Commission, when dealing with questions in the field of private international law, should consider the appropriateness of consultation with the Netherlands Government."

The report came before Sub-Committee 2 of the Legal Committee of the General Assembly in 1947. Several members of the sub-

108. Resolution 14, id. at 43.

109. Report on the Methods for Encouraging the Progressive Development of International Laze and its Eventual Codification, 41 Axr. J. INT'L L. 18 n.1 (Supp. 1947) (Committee Report). See Liang, The General Assembly and the Progressive Devolopment and Codification of International Law, 42 AM. J. INT'L L. 66, 77 n.34 (1948). 
committee took the view that the commission should not concern itself with private international law. It was said, among other things, that it would complicate the election of the members of the commission, if as well as the representation of "the main forms of civilization and the principal legal systems of the world," an equal distribution of experts in public and private international law should also be necessary. Other members were, however, in favor of coverage of private international law, and a common measure of agreement was found by the unanimous adoption, with one abstention, of the following stipulation, which became Article 1(2) of the Statute of the International Law Commission: ${ }^{110}$

"The Commission shall concern itself primarily with public international law, but is not precluded from entering the field of private international law."

The International Law Commission has not, so far, entered the field of private international law. Other organs of the United Nations have engaged in work in that field however. For example, the Economic and Social Council is currently dealing with "Recognition and Enforcement Abroad of Maintenance Obligations." The International Institute for the Unification of Private Law in Rome, originally an agency of the League of Nations, ${ }^{111}$ had done research on this subject since 1929 as a result of suggestions from the International Migration Service and the Social Affairs section of the League of Nations. ${ }^{112}$ Preliminary drafts for a convention had been prepared. In 1945, the Department for Social Affairs of the United Nations suggested to the Institute that it continue the work. A revised draft was submitted to the United Nations' Social Commission. Then, in 1951, the Economic and Social Council asked the Secretary General of the United Nations to prepare a working draft of a model convention or reciprocal law and afterwards to convene a committee of experts with a view to formulating the text of a model convention or model reciprocal law, or both, to be submitted to the council not later than at its sixteenth session for its consideration and recommendations to Governments. ${ }^{113}$ Experts were appointed by the Secretary

110. U.N. General Assembly, Offictal Records, 2d Sess., 6th Comm., (Legal Questions); Summary Records, Meetings Sept. 16 to Nov. 26, 1947, pp. 173, 203,
204.

111. Cf. Pilotti, Activity of the International Institute for the Unification of Private Law in International Institute for THe UnIfrcation of Private LAw, UNIFICATION OF LAW 15 (1948); Wigmore, The Movement for International Assimilation of Private Laze: Recent Phases, 20 ILL. L. Rev. 42, 48, 56 (1925).

112. Pilotti, supra note 111 , at 39.

113. Thirteenth Session, Resolution 390 (XIII). U.N. Documents E/AC. 7/SR 184 and $185 ; \mathrm{E} / \mathrm{SR} .494$. 
General, among them one from the United States. The Committee of Experts produced two drafts, a Draft Convention on the Recovery Abroad of Claims for Maintenance, and a draft of a Model Convention on the Enforcement Abroad of Maintenance Orders. ${ }^{114}$ One of the provisions in the Draft Convention on the Recovery Abroad of Claims for Maintenance is to the effect that no provision of the convention shall be deemed to affect, or to impose, any obligation in respect of any matter not within the constitutional competence of a federal state. ${ }^{115}$ The drafts are scheduled to come before the seventeenth session of the Economic and Social Council in 1954.

\section{XIII.}

There have been recent developments around the Hague Conference on Private International Law which are particularly pertinent to the subject under consideration. ${ }^{118}$ They will therefore be discussed in some detail, the question of the United States' participation in the Hague Conference having arisen.

The Hague Conference on Private International Law held another session, its seventh, in October, 1951. At the sixth session, that of 1928, work had been undertaken on conflict of laws in international sales, and the Government of the Netherlands was asked by the conference to appoint a committee for preparation of a draft convention. The committee produced a draft in 1931 but conditions in Europe did not favor holding another session of the conference. When the recent war was over, the Government of the Netherlands was urged to call another session. In July, 1949, it approached the governments of the nations, which had participated in the earlier session, to ascertain their reaction to a possible call of another session. The memorandum addressed to these governments included the following passage: ${ }^{117}$

". . . the discussions of the Committee on the Progressive Development of International Law and its Codification, established by the United Nations, which took place at Lake Success from May 12 to June 17, 1947, prove that the work of the Hague Conference has been appreciated also outside the circle of the participating nations. . . In fact, it was thought that, in this field, the Conference should pursue its work without disturbance

114. U.N. Document E/AC. 39/1. See Contini, International Enforcenent of Maintenance Obligations, 41 CALIF. L. Rev. 106, 119 (1953).

115. Art. 14 of the Draft Convention, U.N. Document E/AC. 39/1.

116. Cf. Nadelmann, The United States and the Hague Conferences on Private International Law, 1 Ax. J. Comp. L. 268 (1952).

117. Conférence de la Haye de Droit International Prive, Documents RELATIFS À LA SEPTIÈME SESSION 2 (1952); 1949/1950 JAARBOEK VAN HET MINISTERTE VAN BUITENLANDSE ZAKEN 99, 321, 323 (1950) (our transl.). 
of the results by any simultaneous efforts. The Royal Government does not disregard the possible connection between these debates and the future of the Conference of the Hague. It is notably possible that, without explicit expression, these discussions were influenced by the idea of an ultimate increase in the number of nations participating in the Conference. However, the Government has not wished to decide this delicate question without previous consultation with the other nations participating in the Conference. Consequently, the Government of the Netherlands has the intention to put on the agenda of the Seventh session the discussion of a possible increase of the number of nations to be invited to the Eighth session."

Two years passed before the conference met. Other developments had taken place which needed consideration. In the summer of 1949, the Council of Europe had come into existence. Its charter provides that the aim of the Council shall be pursued by its organs through conclusion of agreements and adoption of common action in indicated fields, including the field of law. ${ }^{118}$ In 1950, the Government of Eire, a member of the Council, proposed to the Committee of Ministers of the Council that the possibility of concluding agreements on civil procedure be considered. The Committee of Ministers instructed the secretary general to contact the Hague Conference and the Rome Institute for the Unification of Private Law with regard to a possible study of this question. It further instructed the secretary general to suggest to the Hague Conference that it cause the four countries which are members of the Council of Europe but not members of the Hague Conference-Eire, Iceland, Greece, and Turkey-to join the conference. ${ }^{119}$ In May, 1951, the British Government, following Eire's example, proposed to the Committee of Ministers of the Council of Europe the undertaking of work in the legal field, for example, on acceptance of official documents without requirement of legalization, on judicial assistance, and on recognition of decisions in matrimonial matters. ${ }^{120}$ At that stage the Government of the Netherlands called attention to the achievements of the Hague Conference in the private international law field and to the fact that the conference was about to meet again. It proposed some form of cooperation between the Council of Europe and the Hague Conference under which the conference would handle all questions of private international law for the

118. Charter of the Council of Europe, art. 1(b), 3 International Organizatron 584 (1949). Cf. The Council of Europe, 26 Dep't State Bull. 523 (1952).

119. See Conférence de la Haye de Droit International Privé, Actes de LA SEPTIEMME SESSION 274 (1952).

120. Id. at 277 . 
Council. $^{121}$ The Committee of Ministers postponed consideration of the legal questions until after the session of the Hague Conference and expressed approval of the idea of cooperation. ${ }^{122}$

When the Seventh Conference of the Hague on Private International Law met in October, 1951, the president of the conference, Professor Offerhaus, of the Netherlands, said this in his opening speech on the future of the Conference: ${ }^{123}$

"As we shall not have the time to solve all the problems [on the agenda] it will be good for the Conference to consider the question of a permanent and more visible set-up for the period between sessions. The problems of organization are of such importance that one of our four committees should deal with them. . . The necessity of continuation of the work after the session was demonstrated in the matter of sales. . . . Therefore, an endeavor should be made to find a structure by which the work can be continued by a Bureau and by commissions-and this will raise the question of the role of the Government of the Netherlands and of the Governmental Commission. . . . Furthermore, the Conference will have to consider the question of admission of other nations and of coordinating the work on codification of private international law, in which the governments engage, in particular in relation with the Council of Europe."

Committee IV was asked to consider the creation of a permanent organization and to attend to the communications received from the Council of Europe. The committee produced a draft charter for the Hague Conference on Private International Law, and it drafted principles to govern the relations with the Council of Europe. The Charter and Principles were adopted by the Conference.

The Charter, ${ }^{124}$ consisting of fifteen sections, makes the conference a permanent institution whose aim is to work on the progressive unification of the rules of private international law. ${ }^{125}$ Members of the conference are the countries which accept the Charter and which had participated in earlier conferences. New members may be admitted upon the proposal of a member State, if a majority of the member States are in favor of the admission and the new member accepts the Charter. ${ }^{126}$

121. $I d$. at 280 .

122. Id. at 283.

123. $I d$. at 12 (our transl.).

124. Id. at 398; text also in 40 Revue Critique de Droit Internationat Privé 738 (France 1951). Translation page 363 infra.

125. Charter of the Conference of the Hague on Private International LAw art. 1.

126. $I d$. art. 2. 
The task of assuring the functioning of the conference is given to a standing Governmental Commission of the Netherlands, ${ }^{127}$ which was created by a Royal Decree of $1897^{128}$ to promote the codification of private international law. This commission, composed of Dutch experts in conflict of laws, always has prepared the work of the conferences. The Governmental Commission of the Netherlands is to work through a Permanent Bureau ${ }^{129}$ with the seat at the Hague, composed of a secretary general and two secretaries, who must be of different nationality. The Government of the Netherlands appoints the secretary general and the secretaries on presentation by the Governmental Commission. The Governmental Commission directs the work of the Permanent Bureau. It has power to accept or reject proposals submitted to the conference for inclusion in its work ${ }^{130}$ and fixes dates and agenda of the sessions of the conference after the consultation of the conference members. ${ }^{131}$ Each Government is to designate a national organ or agency for facilitating communications between the members of the conference and the Permanent Bureau. ${ }^{132}$ Regular sessions of the conference are to be held every four years. ${ }^{133}$ Special commissions may be appointed by the conference-or between sessions by the Governmental Commission-to prepare draft conventions and to study questions which are within the scope of the conference. ${ }^{134}$

The expenses of the bureau and of special commissions are to be paid by the member States. Expenses of delegates to special commissions are to be borne by the delegating government. The budget must be approved annually by the diplomatic representatives of the member states accredited at the Hague convening under the chairmanship of

127. Id. art. 3(1).

128. StaAtscourant of Feb. 24, 1897, see [1897] WeEkBLAd VAN HET Recet No. 6924; 3. Exact title: Governmental Commission to Prepare Measures to be taken for the Promotion of the Codification of Private International Law. Cf. 1950/1951 JaARBoEk vaN HET MINISTERIE vaN BUITENLANDSE ZaKEN 208, 209 n. 1 (1951).

129. Charter of the Conference of the Hague on Private International LAw art. 4.

130. Id. art. 3(3). Such proposals may come from without, e.g., from the Council of Europe. It was the International Law Association which suggested the work on conflicts in sales. See CONFERENCE DE LA HAYE DE DROIT INTERNATIONAL Prive, Documents RELATIFs à LA SIXIk̀Me SESSION 469 (1928); InTERNATIONAL Law Association, Report of the 34te Conference, VIEnNa, 1926 507, 669 (1927).

131. Charter of the Conference of the Hague on Private International LAw art. 3(4).

132. Id. art. 6.

133. Id. art. 3(6) and (7).

134. Id. art. 7. 
the Minister of Foreign Affairs of the Netherlands. ${ }^{135}$ The Government of the Netherlands covers the expenses of the regular sessions of the conference, exclusive of the expenses of the delegates. ${ }^{138}$

The Charter provides that the practices of the conference shall remain in force, except where they conflict with the Charter. ${ }^{137}$ Rules to complement the Charter will be drafted by the Permanent Bureau for approval by the member governments. ${ }^{138}$

The Charter enters into force when accepted by a majority of the Governments represented at the seventh session. ${ }^{130}$ Those represented were Austria, Belgium, Denmark, Finland, France, (Western) Germany, Great Britain, Italy, Luxembourg, the Netherlands, Norway, Portugal, Spain, Sweden and Switzerland. Yugoslavia had an observer. The Charter may be amended with the approval of two-thirds of the member governments, ${ }^{140}$ and members of the conference may withdraw after five years. ${ }^{141}$

These are, in brief, the contents of the Charter. The discussions in Committee IV must be considered for its interpretation. They were sometimes confused, as drafting of a Charter had not been on the agenda and the delegates arrived without instructions. It was first thought to have as the governing body a directorate made up of representatives of the member States, ${ }^{142}$ but delegates from smaller countries were concerned about the expenses of a complicated conference set-up. It was finally agreed that the Netherlands Governmental Commission would keep the role it had exercised in the past, ${ }^{143}$ since some representation of the different legal systems could be secured on the Permanent Bureau level, where the secretary general and the secretaries would have to be of different nationalities. ${ }^{144}$

135. Id. art. 8 and 9. The Charter does not indicate how the expenses shall be divided among the members.

136. $I d$. art. 10 .

137. Id. art. 11 .

138. Id. art. 13.

139. $I d$. art. 14.

140. $I d$. art. 12.

141. Id. art. 15.

142. Conférence de la Haye de Droit International Prive, Actes de la SEPTIÈME SESSION 246, 252 et seq. (1952).

143. $I d$. at 258.

144. Id. at 317 et seq. Criticism of the special role given to the Netherlands Governmental Commission, recognized in 1951/1952 JAARBOEK VAN HET MINISTERIE VAN BUITENLANDSE ZAKEN 182, 192-93 (1952), has been voiced in Giannini, I Progetti di Convenzione della VII Conferenza di'Diritto Internazionale Privato, 51 RIvista del DrritTo Commerciale, pt. I, 111, 126 (1953). It is interesting that, some fifty years ago, Simeon E. Baldwin proposed that the Hague Conference should be governed by an international commission, similarly to what the International Penitentiary Commission did for the International Penitentiary Congresses. Baldwin, The Beginnings of an Official Entropean Code of Private International Law, 12 YALE REV. 10, 21 (1903). 
On extension of membership, the discussions show that the speakers thought first of the European countries who were members of the Council of Europe but not members of the Hague Conference. The question of United States participation was brought up by a delegate from Western Germany who said that Americans in Western Germany had expressed surprise at the United States' not having been invited. He added that he thought American participation would be advantageous. ${ }^{145}$ The committee chairman replied that a distinction had to be made between the general issue and the one involving the relations with the Council of Europe. An agreement with the Council might make admission of four new members from Europe necessary, and special reasons were in favor of it; but this did not mean that the door would be closed to other countries. ${ }^{146}$

The United States was once more mentioned, in connection with the language question. Under the practices of the conference, the official language is French but English delegates may use English in the discussions, if immediate translation is provided for. ${ }^{147}$ A delegate from Western Germany suggested that, while French could remain the official language, all delegates should be allowed to use their own languages in exceptional cases. If the membership were to be extended, the use of only one language might prevent States from joining because of lack of experts sufficiently familiar with that language. ${ }^{148}$ Professor Cheshire, one of the British delegates, supported the proposal, adding that he felt the language question should be dealt with in the Charter. He further remarked: "It would be important to admit English as an official language notably in view of the possible entry of the United States in the Conference." ${ }^{149}$ This brought a question from another delegate as to whether the entry of the United

145. Conference de ta Haye de Droit International Privé, Actes de la SEPTIEME SESSION 271 (1952).

146. Ibid.

147. See id. at 247. Cf. Actes de la 5e Conférence de la Haye DE Droit' International Privé 21, 331 (1926).

148. Conference de la Haye de Droit International Privé, Actes de la SEPTIÈME SESSION 334 (1952).

149. Ibid. See also Professor Cheshire's observations on the language question and the absence of the United States before the 1952 International Law Conference of the Grotius Society. Said he, inter alia: "This desirability of advancing the claims and sometimes the superior virtues of the common law when confronted with an array of civilians brings me to the third point. No invitation to attend the conference had been issued to the other common law countries, and so we were the sole representatives of a large part of the world. We certainly kept in close but inofficial touch with the United States embassy, which was not unnaturally interested in what was going on, but it was borne in upon us that a conference without a delegate from the most powerful common law country in the world is but a pale shadow of what it ought to be." Cheshire, The 1951 Hagne Conference on Private International Laze, 38 Grotius Society Transactions 35, 40 (1953). 
States and of other American States was envisaged. ${ }^{150}$ The presiding officer passed the question to the conference chairman who observed that the language question could not well be made dependent upon admission of new States and, in particular the United States, as this problem had not been officially discussed in the committee. ${ }^{161}$. The final decision was to have the practices of the conference remain in force ${ }^{152}$ and leave any other determination to the regulations to be prepared by the Permanent Bureau for approval by all member States.

The 1951 session of the Hague Conference had interesting results on substance. The delegates signed four conventions ad referendum. ${ }^{153}$ Probably the most important, is the Convention on the Law Applicable to International Sales, which was unanimously adopted and which provides that the signatory States shall incorporate the principles of the convention into their law as the domestic law on the subject. It is an open convention to which any nation may adhere. The second convention is on Recognition of the Legal Personality of Foreign Corporations. The third convention, called a Convention to Determine Conflicts between the National Law and the Law of the Domicile, settles some renvoi problems. The last convention is on Civil Procedure, that is, judicial assistance. It is designed to replace the Convention of 1905, which had been ratified by numerous continental countries. Slight changes have been made to make the convention acceptable to the British. Provisions on legal aid have been added. Non-member States may adhere to this convention, provided there is no objection on the part of a ratifying State.

Further results of the conference are requests that the Government of the Netherlands negotiate for the conference an agreement of cooperation with the Council of Europe ; ${ }^{154}$ that the Governmental Commission appoint a special committee for the preparation of a draft convention on conflict of laws in matters of maintenance orders; that it study abolition or simplification of legalization of official documents; and, that it consider the advisability of making further efforts to obtain ratification of the Draft Convention on Recognition and Enforcement

150. Id. at 335 .

151. Ibid.

152. See id. at $336,337,338$.

153. For the text, see $i d$. at 382 et seq.; and 40 Revue Critique de Droit International Privé 725 et seq. (France 1951). Translation in 1 Am. J. Comp. L. 275 et seq. (1952). See Offerhaus, The Seventh Session of the Hague Conference on Private International Law, 79 CLUNET 1071-1137 (France 1952); Wortley, The 1951 Hague Conference on Private International Law, 38 Grotrus SoCIETY TransaCtrows 25 (1953); Cheshire, $38 \mathrm{Id}$. at 35 (on the renvoi convention).

154. Conférence de la Haye de Drott Internatonal Privé, Actes de la SEPTIÈME SESSTON 402 (1952). 
of Foreign Judgments, ${ }^{155}$ which was prepared at the 1925 and 1928 sessions of the conference. ${ }^{156}$ Other resolutions of the conference call for the establishment of special committees to prepare a draft convention on transfer of title in.international sales, so far as this question is not dealt with in the Sales Convention, and a draft convention on jurisdiction in international sales. ${ }^{157}$

The question of ratification of the Charter and draft conventions is presently being studied by the governments of the member States. ${ }^{157 a}$ In Great Britain, since the conference, the Lord Chancellor has appointed a Standing Committee on Private International Law. ${ }^{158}$ Among its assignments is the consideration of the results of the Hague Conference and the submission of recommendations on the report of the conference.

\section{XIV.}

Immediately following the October, 1951, session of the Hague Conference on Private International Law, there was another diplomatic conference held at the Hague on a subject of unification of the law. This was a conference which the International Institute for the Unification of Private Law in Rome had requested the Government of the Netherlands to call for the consideration of a draft of a Uniform Law on the International Sale of Goods prepared by the Institute. The Government of the Netherlands agreed, and invitations were addressed to the States which were members of the Rome Institute and to other governments which had announced their intention to take part in the Conference on Private International Law. ${ }^{159}$ Thus representatives of twenty-two governments met at the Hague in November, 1951. ${ }^{160}$ The Government of the United States sent an observer to the conference. ${ }^{101}$ The draft law prepared by the Institute was ac-

155. Id. at 401.

156. See Actes de ia 5e session de la Conference de ia Haye de Droit

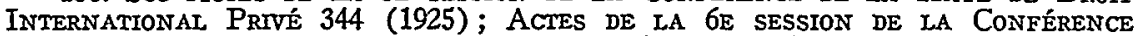
de la Haye de Drott International Prive 421, 422 (1928).

157. Conférence de la Haye de Droit International Privé, Actes de la SEPTIEMAE SESSION 401 (1952).

157a. On the status. of ratifications of the Charter, see M. v. H., Quelques notes sur les travaux de la Conférence de la Haye de Droit International Privé, 1 Nederlands Tijdschrift voor Internationaal Recht 78, 79 (1953).

158. See 102 L.J. News 586 (1952); 214 L.T. 199 (1952).

159. See International Institute for the Unification of PrIVATE Law, 1950 Report ON THE ACTIVITY OF THE INSTITUTE 17, 21 (1951); 1950/1951 J AARBoek VAN HET MINISTERIE VAN BUITENLANDSE ZAREN 211 (1951).

160. See Actes de ia Conférence convogutée par ie Gouvernement Royal DES PAYS-BAS SUR UN PROJET dE CONVENTION RELATIF À UNE LOI UNIFORME SUR LA VENTE D'OBJETS MOBILIERS CORPORELS, LA HAYE, 1ER-10 NoveMrbre 1951 (1952).

161. Ibid. 
cepted as the basis for future work which was entrusted to a Working Committee appointed by the conference. ${ }^{162}$

The Rome Institute, ${ }^{163}$ founded by the Italian Government in 1926, had originally been made available to the League of Nations for work on unification of the law. When Italy withdrew from the League, the Institute was reorganized by the Italian Government and given an organic statute. Under this statute, ${ }^{164}$ dated March 15, 1940, the Institute is an international institution dependent on the participating governments, that is, those governments which signify their acceptance of the statute. ${ }^{165}$ The object of the Institute is to study the means by which to harmonize and coordinate the private law between States or groups of States and to prepare gradually for the adoption of uniform private law legislation by the various States. The organs of the Institute are: (1) the General Assembly, composed of a representative of each participating Government, (2) the President, appointed by the Italian Government, (3) the Governing Council, composed of the President and members chosen by the General Assembly, (4) the Permanent Committee, composed of the President and four members chosen by the Governing Council from among its members, (5) the Secretariat, composed of a Secretary General appointed by the Governing Council on the proposal of the President, and two Assistant Secretaries General of different nationalities appointed by the Governing Council. ${ }^{166}$ The budget provides for a fixed contribution by the Italian Government, which provides also the offices, and for voluntary contributions by other Governments. ${ }^{167}$ About thirty Governments, European and Latin American, have adhered to the statute. As of December 31, 1952, voluntary contributions were received from Austria, Belgium, Brazil, Finland, France, (Western) Germany, Great Britain, Greece, San Marino, Sweden, Switzerland and Turkey. ${ }^{168}$ In 1951, a jurist from the United States was elected to the Governing Council. ${ }^{169}$ The Institute has also "Corresponding Collaborators" in the United States. ${ }^{170}$

162. See Rabel, The Hague Conference on the Unification of Sales Law, 1 AM. J. COMP. L. 58 (1952); INTERNATIONAL INSTITUTE FOR THE UNIFICATION OF Private Law, 1952 Report on the Activity of the Institute 21 et seq. (1952). 163. See Pilotti, op. cit. supra note 111, at 15.

164. 8 Hudson, International Legislation 455 (1949). See 3 Dep't State BulL. 109, 286 (1940).

165. Organic Statute of the Rome Instrtute art. 2 (binding for six years: art. 20).

166. Id. art. $4-8$

167. Id. art. 16.

168. Internatronal Institute for the Unification of Private Law, 1952 REPORT ON THE ACTIVITY OF THE INSTITUTE 15 (1952).

169. Id. 1951 REPORT 11, 12 (Professor Hessel E. Yutema).

170. Id. 1952 REPORT 9. 
In addition to preparing the draft of a Uniform Law on the International Sale of Goods, the Institute has been working in recent times on drafts for uniform laws on Conclusion of Contracts by Correspondence, Agency in International Relations, Contracts for Mercantile Agency, Arbitration in International Private Law Relations, and other topics. ${ }^{171}$ It has done work for the Department of Social Affairs of the United Nations and has been consulted by the Council of Europe. It is engaged in negotiations with the Council of Europe, as is the Hague Conference on Private International Law, for a working agreement with that Council. ${ }^{172}$

\section{XV.}

A study of the record of international efforts in the field of unification of rules of private international and commercial law, where United States participation was sought, is being sought, or has been obtained, reveals the existence of numerous problems worthy of greater consideration than they have heretofore received. The only problem that can be discussed here, however, is the one concerning the interests of the states of the Union in such efforts and the consideration given, or not given, them by the United States Government, when questions arise within the jurisdiction of the states.

Here comment can be brief, as the record speaks for itself. In most instances, particularly in the past, the Federal Government thought that it had fulfilled its duty when it stated that the subject under consideration was not within the jurisdiction of the Federal Government and not suitable for use of the treaty-making power. The states were neither consulted nor given an opportunity to say, if such was the case, that they had an interest in furthering the efforts made to secure uniformity of the law.

Where the Federal Government collaborates in unification efforts, as in the case of the Inter-American Council of Jurists, there is no evidence that contact with the states is maintained as to the topics that are in the state law field. Nor does it seem that such contact is established when private citizens serve on councils and expert committees. At any rate, ready-made machinery for such contacts does not exist.

171. Id. at 23 et seq.

172. See 3 Councir of Europe News, No. 10, 15 (Oct. 1953). Under art. 12 bis of the Organic Statute, the Governing Council may establish with other intergovernmental organizations as well as with non-participating governments relations proper to secure collaboration in conformity with their respective aims. 
In Missouri v. Holland, Mr. Justice Holmes said in discussing the extent of the treaty-making power under the Federal Constitution: ${ }^{173}$

".. . when we are dealing with words that also are a constituent act, like the Constitution of the United States, we must realize that they have called into life a being the development of which could not have been foreseen completely by the most gifted of its begetters. It was enough for them to realize or to hope that they had created an organism; it has taken a century and has cost their successors much sweat and blood to prove that they created a nation."

The consequences of the growth of a huge mass of widely differing law in the states were not fully anticipated; they could not be, the more so because law which today is considered local, at that time was held to be "general." 174 Thus wide areas of the law, where uniformity is needed, internally, and sometimes also internationally, are not amenable to federal legislation. And when the problem of unification arises internationally, a gap appears in constitutional organization. Under the Federal Constitution, the states may, with the consent of Congress, enter into agreements or compacts with foreign powers. ${ }^{175}$ This would require proper representation of the states in international efforts for the unification of the law. Nothing has been done, so far, to provide for that representation. ${ }^{176}$ Conclusion of formal agreements or compacts by the states is not the only available way; it is not even the one customarily employed within the Union for unification of the law. The informal system of adopting uniform laws or model laws is available also on the international level; but here again, due representation of the states is necessary and machinery for such representation is lacking at present.

More than sixty years ago, need for uniformity of the law among the states of the Union led to the creation of the National Conference

173. 252 U.S. 416,433 (1919).

174. E.g., Miller v. Hall, 1 Dallas 229 (Pa. 1788) (conflict of laws); Steinmetz v. Currie, 1 Dallas 270 ( $\mathrm{Pa}$. 1788) (negotiable instruments law).

175. U.S. Const. Art. I, $\$ 3$, cl. 3.

176. A step, the first, toward using the compact device in the international field has been made in connection with the Northeastern Interstate Forest Fire Protection Compact, approved by Congress, 63 STAT. 271 (1949). The compact is designed to promote fire prevention in the northeastern region of the United States and adjoining areas in Canada. Any state or any Canadian Province contiguous with one of the member states may become a party to it but "before any province of the Dominion of Canada shall be made a party to such compact, the further consent of Congress shall first be obtained." Ibid. No Canadian Province has so far become a party to the compact. See 1950-1951 Book of THE STATES 25 (1951); Thursay, Interstate CoOperation-A Study of the Interstate Compact 105 (1953). 
of Commissioners on Uniform State Laws. ${ }^{177}$ In fact, the idea of appointing such commissioners had been advanced much earlier. ${ }^{178}$ Together with other reasons, the same need for internal uniformity of the law led, more than thirty years ago, to the creation of the American Law Institute and the undertaking of the restatement of the law. ${ }^{179}$ In both instances, the assigned task has been limited to the domestic field. ${ }^{180}$ Where uniformity among the laws of the states of the Union and the laws of other nations appears desirable and practicable, the vacuum appears. No machinery has been set up to have the states' interests represented here in an adequate and practical way. ${ }^{181}$

Agreement seems to exist that reference to the treaty-making power of the Federal Government is no answer. This power should not be stretched so as to cover areas for which it was not created. In this respect, it interesting to note that the record shows little inclination on the part of succeeding administrations to enter the state law area for purposes of unification of the law through use of the treaty-making power. Still remembered is Charles Evans Hughes' comment at the annual meeting of the American Society of International Law where the nonsigning of the Bustamante Code of Private International Law was discussed: ${ }^{182}$

"In connection with that effort doubtless there were many matters considered which were not entirely of local concern, but here and there there would be matters which were exclusively within the local jurisdictions, which had no international relation at all except in the desire to get rid of a conflict of doctrine or a conflict of laws and to establish a uniform law . . . [F]rom

177. For the history, see 1952 Handbook of the National Confrerence of COMMISSIONERS ON UNIFORM STATE LAWS 525 et seq. (1952).

178. See Note, On a Uniform Criminal Code for the United States, 7 Albany L.J. 146, 147 (1873). The drafting by national commissioners of a universal code of private international law under a David Dudley Field proposal was given as precedent to be followed. See FIELD, DrafT-OUTLINES OF AN INTERNATTONAL CoDE preface i-ii (1876) ; Field, On a Project for an International Code, in TransacTIONS MANCHESTER supra note 6, at 50 (1866).

179. See Lewis, History of the American Law Institute and the First Restatement of the Lave in Restatement IN THE Courts 1 et seq. (Permanent ed. 1945).

180. The National Conference of Commissioners on Uniform State Laws has, under its Constitution, Art. I (2), as its objects (1) the promotion of uniformity in state laws on all subjects where uniformity is deemed desirable and practicable; (2) the drafting of model acts on (a) subjects suitable for interstate compacts, and (b) subjects in which uniformity will make more effective the exercise of state powers and promote interstate cooperation; (3) the promotion of uniformity of judicial decisions throughout the United States. 1952 HANDBOOK OF THE NATIONAL CONFERENCE OF Commissioners on UnIforar State Laws 525 et seq. (1952). 181. Even with Canada, where the Conference on Uniformity of Legislation in Canada is the counterpart to our National Conference, cooperation is still a matter for the future. The assignment given to the Commissioners in Canada is similar to the one given to our Commissioners. A difference is that the Dominion itself sends Commissioners to the Conference. See MacTavish, Untiformity of Legislation in Canada-An Outline, 25 CAN. B. REv. 36, 48 (1947).

182. 23 Proc. Am. Soc'y INT'L L. 195-96 (1929). 
my point of view the nation has the power to make any agreement whatever in a constitutional manner that relates to the conduct of our international relations. . . . But if we attempted to use the Treaty-Making power to deal with matters which did not pertain to our external relations but to control matters which normally and appropriately were within the local jurisdictions of the states, then I again say there might be ground for implying a limitation upon the Treaty-Making power . . . ."

As a general proposition, perhaps for constitutional reasons and certainly for political reasons, the interests of the states in their areas must be taken care of otherwise than by the Federal Government resorting to its treaty-making power.

The difficulties arising in the representation of interests of members of a federal state on the international level, well known particularly in the field of international labor legislation, ${ }^{183}$ are not peculiar to the United States. They have arisen in dealings involving federal systems of government generally; except that, in constitutions of more recent date than our own Constitution, the area of federal law has been broadened, sometimes by the means of constitutional amendment, ${ }^{184}$ to include fields where experience has shown the desirability of internal uniformity of the law. ${ }^{185}$ And, desirability of internal uniformity and wishes for, international uniformity often run parallel. While the process of constitutional amendment has had distinguished advocates, ${ }^{186}$ its use for this purpose cannot be expected at least in the near future.

But the desirability of attaining internationally greater uniformity or better co-ordination for certain rules of law in the conflicts and commercial law fields is an actual and acute problem. The problems

183. They led to an amendment of the Constitution of the International Labor Organization in 1946 under which, in respect to conventions and recommendations, which a federal government regards as appropriate, in whole or in part, for action by the constituent states rather than for federal action, the federal government is required to make arrangements for the reference of such conventions or recommendations to the appropriate federal or state authorities, and to arrange, subject to the concurrence of the state governments concerned, for periodical consultations between the federal and state governmerts concerned, with a view to promoting within the federal state co-ordinated action to give effect to the provisions or recommendations. ILO Const. Art. 19(7), as amended. See 1 The International Labour Code preface $1 \times x x$ (1951).

184. Federal jurisdiction was continuously extended, notably in Switzeriand, merely procedural law remaining left to the cantons.

185. E.g., negotiable instruments: British North America Act, 1867, art. $91(18)$ in 1 Peaslee, Constitutions of Nations 336 (1950); Australian Constitution of 1900 art. 51 (xvr), in 1 PEASLEe at 100; Indian Constitution of 1949 art. 246, Seventh Schedule, List I No. 46. See BAsU, A Commentary on the Constitution OF INDIA 944 (2d ed. 1952).

186. E.g., Story, SkETCH OF AMERICAN LAw, written in 1834, to be published in 3 AM. J. CoMp. L. No. 1 (1954). Constitutional amendment after achievement of uniformity by way of uniform legislation was considered probable if not anticipated in the 1891 Report of the American Bar Association Committee on Uniform State Laws, 14 A.B.A. Rep. 365, 374 (1891). 
well known from the domestic scene re-appear internationally; suffice it to refer to topics like negotiable instruments, sales and enforcement of judgments and maintenance orders. They appear with the same characteristics; which makes, for example, any general codification of conflicts law as undesirable internationally as it is nationally for the time being. ${ }^{187}$ The practicability of attaining greater uniformity, or better co-ordination, is a matter of opinion. Success in the long run, at least as to some topics, cannot be ruled out. Domestic experience has shown limitations as well as possibilities, and the same is true for the international field, where difficulties increase when differences between the common law and the civil law systems must be bridged. But such bridging is not impossible. For example, between the two world wars, Great Britain was able to conclude more than twenty conventions with civil law countries, ${ }^{188}$ on judicial assistance, a topic which is of special concern to our own bar. ${ }^{189}$ By codifying the common law rules on recognition of foreign judgments and by creating registration facilities for enforcement purposes, ${ }^{190}$ Great Britain has been able, in the years before the last war, to make agreements with France ${ }^{191}$ and other nations on reciprocal enforcement of their judgments, under which judgments from British courts are given recognition as to the merits, instead of being subjected to a general review, as are judgments from our own courts. ${ }^{192}$ What in this instance was done by enactment in Great Britain, can, in this country, be done by legislation in the states; ${ }^{193}$ reciprocity arrangements can be made by our Federal Government with foreign nations for the benefit of those of our states which will pass legislation of the

187. Herbert F. Goodrich, in a letter of Feb. 23, 1949 to the Commissioners on Uniform State Laws, stated: "I should not like to see an attempt to codify conflict of laws now. I think we need more years of experience and discussion." 1949 HANDBOOK OF THE National Conference of CoMmissioners on UNIForm State LAws 79 (1949).

188. See 1952 Andudal Practice 648, 649 (1952).

189. See Jones, International Judicial Assistance: A Program for Reform, 62 YALE L.J. 515 (1953); Boston Resolution of the $A B A$ Section on International and Comparative Law, 39 A.B.A.J. 935 (1953), approved by House of Delegates, 40 id. at 67 (1954). c. 13

190. Foreign Judgments (Reciprocal Enforcement) Act, 1933, 23 \& 24 GEo. 5,

191. Convention of Jan. 18, 1934, Providing for the Reciprocal Enforcement of Judgments in Civil and Commercial Matters, 171 League of Nations Treaty SERIES 183 (1936).

192. See Nadelmann, Reprisals Against American Judgments?, 65 Harv. L. REv. 1184, 1187 (1952).

193. See discussion of the subject in American Judgments Abroad, 8 Recond 302 (1953) (The Record of the Association of the Bar of the City of New York) (Report of the Committee on Foreign Law). For a more detailed discussion, see Nadelmann, The United States of America and Agreements on Reciprocal Enforcement of Foreign Judgments, 1 NEDERLANDS TIJDSCHRIFT vOOR INTERNATIONAAL RECHT-(1954). 
type set forth in the agreement. ${ }^{194}$ But nothing of the sort can be successfully undertaken without the representation of the interests of the states.

Thus proper internal arrangements are needed to have the state interests in international efforts to unify rules of law duly and effectively represented. The policy of the past, as evidenced by the record, has been all but constructive. The search for a solution of the problem should not be delayed, because sooner or later, decisions of national import must be taken with regard to United States' participation in the international efforts to unify rules of private international and commercial law. Inasmuch as the questions involved also affect the foreign relations of the United States, there seems to be a constitutional duty on the part of the Federal Government to ascertain the national interest for both the federal and state law areas. Consultations with expert groups on international law and representative bodies like the American Law Institute and the National Conference of Commissioners on Uniform State Laws suggest themselves. These consultations might lead to creation of a standing advisory body, duly composed to cover the federal law as well the state law areas, with the function of assisting the executive branch of the Federal Government in international dealings involving unification of the law.

As for the present situation, what the Wigmore Report told the National Conference of Commissioners on Uniform State Laws in 1921 still holds true: ${ }^{195}$

“. . . [I]f a world-conference has adopted a uniform code with American ideas left out, the Legislatures of America will be obliged either to adopt it in its foreign shape moulded by the bargains of foreign powers among themselves, or to reject it and thus remain behind in the highroad of international unity, suffering all the disadvantages of diversity and conflict of laws. They will in either case have lost the chance of impressing upon international legislation something of American features."

194. See the British Convention with France, supra note 191, which in art. 13 provides that any member of the British Commonwealth accepting the terms of the Conyention may accede to it. New Zealand passed enforcement legislation for foreign judgments and took advantage of the possibility. N.Z. Reciprocal Enforcement of Judgments Act, 1934, [1934] N.Z. STAT. 49; Reciprocal Enforcement of Judgments (France) Rules 1938, [1938] N.Z. Sratutory Regulations No. 176, 734. On accession, see Stewart, Treaty Relations of the BritisH Commonwealth of Nations 247 (1939). For plans in Canada to draft a Uniform Reciprocal Enforcement of Foreign Judgments Act, to facilitate international negotiations, see 1939 ProceEdings of THE CoNfERENCE OF CoMmissioners oN UNIFORMITY OF LEGISlation in Canada 42 et seq. (1939), 24 Can. B. Ass'n Proc. 274 et seq. (1939); 1951 Proceedings of the Conference of Commisstoners on UNIFORAITY OF LegisIATION IN CANADA 20, 46 (1951).

195. 1921 Handbook of the National Conference of Comaissioners on UNIform State Laws 328 (1921). Cf. Cheshire, supra note 149. 


\section{APPENDIX}

Draft Charter of the Conference of the Hague on Private INTERNATIONAL LAW

The Governments of the States hereinafter enumerated:

Considering the permanent character of the Hague Conference on Private International Law; Desiring to accentuate this character; and Holding it desirable for that purpose to provide the Conference with a Charter:

Agree on the following provisions:

Art. 1. The Conference of the Hague has the aim to work on the progressive unification of the rules of private international law.

Art. 2. (1) Members of the Hague Conference on Private International Law are the States which have already participated in one or more sessions of the Conference and which accept the present Charter.

(2) Other States whose participation represents an interest of juridical nature for the work of the Conference may become members of the Conference. The admission of new members is decided by the Governments of the participating States, on the proposal of one or more of them, by the majority of the votes expressed within six months from the day of the submission of the proposal to the Governments.

(3) The admission becomes effective with the acceptance by the interested State of this Charter.

Art. 3. (1) The functioning of the Conference is secured by the Netherlands Governmental Commission created by Royal Decree of Feb. 20, 1897 to promote the codification of private international law.

(2) This Commission secures the functioning through a permanent Bureau whose activities it directs.

(3) The Commission examines all proposals designated to be put on the agenda of the Conference. It is free in the determination of the disposition to be given to these proposals.

(4) The Governmental Commission determines date and agenda of the sessions after consultation of the members of the Conference. 
(5) It asks the Government of the Netherlands to call the members in session.

(6) The ordinary sessions of the Conference take place every four years, in principle.

(7) If necessary, the Governmental Commission may, after receipt of favorable reactions from the members, request the Government of the Netherlands to call the Conference in extraordinary session.

Art. 4. (1) The Permanent Bureau has its seat at the Hague. It is composed of a secretary general and two secretaries belonging to different nationalities who are appointed by the Government of the Netherlands upon presentation by the Governmental Commission.

(2) The secretary general and the secretaries shall possess proper legal knowledge and practical experience.

(3) The number of the secretaries may be augmented after consultation of the members of the Conference.

Art. 5. Under the direction of the Governmental Commission, the Permanent Bureau is in charge:

(a) of the preparation and organization of the sessions of the Hague Conference, as well as of the meetings of special commissions;

(b) of the work of the secretariat for the sessions and the meetings above mentioned;

(c) of all duties belonging to the activities of a secretariat.

Art. 6. (1) To facilitate communications among the members of the Conference and the Permanent Bureau, the Government of each member shall designate a national organ.

(2) The Permanent Bureau may correspond with all national organs thus designated and with competent international organizations.

Art. 7. The Conference and, between sessions, the Governmental Commission may create special commissions for the elaboration of draft conventions or for the study of questions of private international law within the scope of the Conference.

Art. 8. The expenses of the functioning and maintenance of the Permanent Bureau and of the special commissions are divided among 
the members of the Conference, with the exception of the travel and stay indemnities of the delegates to the special commissions, which shall be covered by the Governments represented.

Art. 9. (1) The budget of the Permanent Bureau and of the special commissions is each year submitted for approval to the diplomatic representatives of the members at the Hague.

(2) These representatives also determine the distribution among the members of the expenses charged to them by the budget.

(3) For that purpose, the diplomatic representatives meet under the chairmanship of the Minister of Foreign Affairs of the Netherlands.

Art.10. (1) The expenses resulting from the ordinary sessions of the Conference are covered by the Government of the Netherlands.

(2) In the case of an extraordinary session the expenses are divided among the members of the Conference represented at the session.

(3) In all cases, the travel and stay indemnities of the delegates are covered by their respective Governments.

Art. 11. The practices of the Conference shall continue to be in force for all that is not contrary to the present Charter or the Regulations.

Art. 12. Modifications may be made in the present Charter if they are approved by two-thirds of the members.

Art.13. To provide for their execution, the provisions of the present Charter will be complemented by Regulations. The Regulations shall be established by the Permanent Bureau and submitted to the Governments of the members for approval.

Art. 14. (1) The present Charter will be submitted for acceptance to the Governments of the States which have participated in one or more sessions of the Conference. It will take effect once it has been accepted by the majority of the States represented at the seventh session.

(2) The declaration of acceptance shall be deposited with the Government of the Netherlands, which will give notice of the deposit to the Governments indicated in the first paragraph of this article. 
(3) The same shall apply, in the case of admission of a new State, to the declaration of acceptance of that State.

Art. 15. (1) Each member may denunciate the present Charter after a period of five years from the date it entered into effect as provided for in the first paragraph of article 14.

(2) The denunciation shall be notified to the Minister of Foreign Affairs of the Netherlands at least six months before expiration of the budget year of the Conference and will take effect at the expiration of that year, but only with regard to the member having given notice of denunciation. 